\title{
Proximate, Mineral Composition, Phytochemical Constituents and Characterization of Oil of Citrullus Lanatus Seeds
}

\author{
Uzama Danlami ${ }^{1, ~ *, ~ B w a i ~ D a v i d ~ M a c h a n ~}{ }^{1}$, Magu Joshua ${ }^{2}$, Kabir Musa Galadanchi, \\ Oloninefa Stephen Dare ${ }^{4}$ \\ ${ }^{1}$ Chemistry Advanced Laboratory, Sheda Science and Technology Complex (SHESTCO), Garki, Abuja, Nigeria \\ ${ }^{2}$ Department of Medical Laboratory Science,Shehu Idris College of Health Sciences and Technology, Makarfi, Kaduna, Nigeria \\ ${ }^{3}$ Department of Chemistry, National Open University of Nigeria, Katsina, Nigeria \\ ${ }^{4}$ Department of Microbiology, Federal University of Technology, Minna, Nigeria
}

\section{Email address:}

uzamadan@yahoo.com (U. Danlami)

\section{To cite this article:}

Uzama Danlami, Bwai David Machan, Magu Joshua, Kabir Musa Galadanchi, Oloninefa Stephen Dare. Proximate, Mineral Composition, Phytochemical Constituents and Characterization of Oil of Citrullus Lanatus Seeds. American Journal of Bioscience and Bioengineering. Vol. 3, No. 5, 2015, pp. 72-75. doi: 10.11648/j.bio.20150305.18

\begin{abstract}
The proximate, mineral compositions, phytochemical constituents and characterization of oil of Citrullus Lanatus were investigated. Atomic Absorption Spectroscopy was employed in determining the mineral composition of the oil, while standard methods were employed in carrying out the proximate, phytochemicals and characterization of the oil. The proximate composition revealed the presence of moisture $6.61 \%$,ash $3.07 \%$,crude fibre 3.51 ,crude fat 35.04 ,crude protein $30.29 \%$ and carbohydrate $21.48 \%$. The mineral composition revealed the presence of Nickel $0.00295 \mathrm{mg} / \mathrm{g}$, Chromiunm $0.00301 \mathrm{mg} / \mathrm{g}$, Manganese $0,002001 \mathrm{mg} / \mathrm{g}$, Iron $0.05396 \mathrm{mg} / \mathrm{g}$, Copper $0.02736 \mathrm{mg} / \mathrm{g}$, Zinc $0.09035 \mathrm{mg} / \mathrm{g}$, Magnesium $0.29118 \mathrm{mg} / \mathrm{g}$. The phytochemical constituents present were tannins, steroids, alkaloids, terpenoids, flavonoids, cardiac glycosides, volatile oil, balsams and phenols. The physicochemical properties revealed the presence of acid value $2.234 \mathrm{mg} / \mathrm{NaOH} / \mathrm{g}$, saponification value $227.5618 \mathrm{mg} / \mathrm{NaOH} / \mathrm{g}$, peroxide value $20.37 \mathrm{mEq} / \mathrm{kg}$, free fatty acid $1.1162 \mathrm{~g}$,viscosity $44.4 \mathrm{~mm} 2 / \mathrm{sec}$, density $0.918 \mathrm{~g} / \mathrm{ml}$ and moisture $0.49 \%$.The results indicated that the Citrullus lanatus seed oil is edible because of the low acid value and free fatty acid value and the seeds contain essential nutrients which compete favourably well with those of other seeds in literature and it is suitable for health benefits.
\end{abstract}

Keywords: Moisture, Balsam, Tannins, Chromium, Absorption, Acid Value

\section{Introduction}

Nutrition is the intake of food, considered in relation to the body's dietary needs. Good nutrition and adequate well balanced diet combined with regular physical activity is the cornerstone of good health.

Fruits are nature's wonderful gift to mankind, indeed, they are medicines packed with vitamins, minerals, antioxidants and many phytonutrients. They are an absolute feast to our sight, not just because of their colour and flavour, but for their unique nutrition profile that helps human body to be free of diseases and keep healthy.

Citrullus lanatus (watermelon) is an edible fruit which belongs to the family named cubitaceae. The fruit contains many obovate smooth compressed seeds thickened at the margin and of a black or yellowish white colour [1]. Citrullus lanatus plays a very important role in Africa as it is used to quench thirst when there is shortage of water [2] .The seed of Citrullus lanatus can be bruised and rubbed up with water to form an emulsion which can be used to cure catarrhal infections, disorders of the bowels, urinary passage and fever. It is also being used to expel tape worm [1].

Citrullus lanatus seed oil is light, penetrating and rich in essential fatty acids [3].

This research was aimed at evaluating the nutritional value, phytochemical constituent and characterization of the oil of Citrullus lanatus seed and to determine its edibility. 


\section{Materials and Methods}

The Citrullus lanatus seeds were obtained from fruit market, a local market in Zuba, Abuja, Nigeria. The fresh seeds were washed and dried in an oven at $40^{\circ} \mathrm{C}$.

The dried seeds sample were ground into powder using mortar and pestle and stored in a container for all the chemical analysis. The oil content was extracted by soxhlet extraction method.

\subsection{Proximate Analysis}

The proximate analysis was carried out in duplicate and the results obtained were averaged for the seeds. The estimation of various physicochemical analysis were determined by using the method of the AOAC [4].

Mineral analysis was carried out using $1 \mathrm{~g}$ of the seed sample. $10 \mathrm{ml}$ of Nitric acid was added to it and digested until a clear solution was obtained. The digest was allowed to cool and filtered using a Whatman filter paper and made up to mark with deionized water. The mineral elements were analyzed with Atomic Absorption Spectrometer (GBC Avanta ver 2.02 model Australia) equipped with airacetylene flame. The viscosity of the oil value was determined by pouring the sample into the viscosity apparatus, time in seconds required for the flow was recorded multiplied by the constant 0.1 . The density of the oil was taken using a density bottle.

Thin-layer chromatography was carried out on the sample with different solvent system.

Chloroform: methanol: water

Ratio 65: 25: 4

Chloroform: methanol: ammonium hydroxide

Ratio 65: 25: 4

\subsection{Hexane and Ethanol Extraction of Seed's Oil}

The hexane and ethanol extracts were extracted from the resulting powder by adopting the method described by AOAC [5], which entailed using soxhlet apparatus to extract with hexane and ethanol. The ground seeds (245.804g) was packed and inserted into the soxhlet extractor and hexane was used as extracting solvent for a period of eight hours. At the end of this period, the solvent was recovered by rotary evaporator and ethanol was also used as extracting solvent for another period of eight hours. At the end of this period, the solvent was recovered by rotary evaporator. The two extracts were then transferred to a water bath for the remaining solvent to evaporate. The extract was allowed to cool before being kept for analysis.

\subsection{Phytochemical Screening}

Chemical tests were carried out on the hexane and ethanolic extracts for the qualitative determination of phytochemical constituents as described by [6-8].

\section{Results and Discussion}

\subsection{Proximate Composition}

The proximate composition of Citrullus lanatus seeds is presented on Table1.The moisture content of the seeds was $6.61 \%$ and falls within the range of moisture contents of similar seeds. The ash content was $3.07 \%$. The ash in food contributes to the residue remaining after the moisture has been removed as well as organic materials. Ash content is generally taken to be a measure of the mineral content of the original food [9].Crude fibre in food is an indication of the level of non-digestible carbohydrate and lignin. In Citrullus lanatus seeds, the value of crude fibre is $3.51 \%$.Although crude fibre enhances digestibility, its presence in high level can cause intestinal irritation, lower digestibility and decreased nutrient usage. The crude lipid content obtained was $35.04 \%$.Lipid provides very good sources of energy and aids in transport of fat soluble vitamins, insulates and protects internal tissues, and contributes to important cell processes $[10,11]$. It is good to add lipid to most of our diets, because many body functions depend on lipids. The crude protein of Citrullus lanatus seeds is $30.29 \%$.

The Recommended Dietary Allowance (RDA) for protein is $56 \mathrm{~g}$ for individual weighing $70 \mathrm{~kg}$ and $46 \mathrm{~g}$ for adult weighing $50 \mathrm{~kg}$, children may consume $2 \mathrm{~kg} /$ day [10]. The seeds of Citrullus lanatus is a good source of protein.

According to Pamela et al [11], protein from plant sources have lower quality but their combination with many other sources of protein such as animal protein may result in adequate nutritional value.

Table 1: Chemical composition of Citrullus lanatus seeds.

\begin{tabular}{ll}
\hline Components & Values $(\mathbf{n}=\mathbf{3}, \mathbf{\%})$ \\
\hline Moisture & $6.61 \pm 0.35$ \\
Ash & $3.07 \pm 0.24$ \\
Crude fibre & $3.51 \pm 0.36$ \\
Crude protein & $30.29 \pm 0.00$ \\
Carbohydrate & $21.48 \pm 0.00$ \\
Crude lipid & $35.04 \pm 1.18$ \\
\hline
\end{tabular}

\subsection{Mineral Composition}

Table2 presents the result of mineral element composition of the seeds of Citrullus lanatus in $\mathrm{mg} / \mathrm{g}$. The value obtained for calcium was $1.12933 \mathrm{mg} / \mathrm{g}$.

The RDA for calcium is $600-1400 \mathrm{mg}$.Calcium is essential for bone and teeth formation and development, blood clothing and for normal functioning of heart, nervous system and muscles. Calcium deficiency can lead to ricket, osteomalacia and tooth decay [12].Excess calcium may in the soil interfere with phosphorus nutrient and may encourage chlorosis because of reduction of soil manganese, iron and zinc [13].The manganese content of the seed of Citrullus lanatus seed was $0.02001 \mathrm{mg} / \mathrm{g}$.

The RDA for manganese varies between $2 \mathrm{mg} / \mathrm{kg}$ to $8 \mathrm{mg} / \mathrm{kg}[10]$.

Certain trace elements such as copper, iron, manganese, constitute essential part of any balanced diet. Some of them 
are micro nutrients, if not present in the right proportion may have adverse effect on human and plant. The copper content was $0.02736 \mathrm{mg} / \mathrm{g}$. The RDA of copper according to Jones et al [10] is $3.5 \mathrm{mg}$.Copper is very vital in diet because it is involved in the proper usage of iron and especially for the synthesis of cytochrome oxidase, which contains both iron and copper. Excess copper can lead to jaundice (Wilson's disease).

The zinc content was $0.09035 \mathrm{mg} / \mathrm{g}$. The RDA for zinc is $13 \mathrm{mg} / \mathrm{kg}$ [10].Zinc is essential in the activation of certain enzymes, these include: dehydrogenase, alkaline phosphatase and carboxypeptdes. Zinc containing organic compounds is employed as astringent and antifungal agents. It aids wound healing and metabolism of nucleic acid and insulin. Zinc in excess causes anaemia and if deficient in the body can lead to dermatitis.

Table 2: Mineral composition of Citrullus lanatus seeds.

\begin{tabular}{ll}
\hline Minerals & Concentration $(\mathbf{m g} / \mathbf{g})$ \\
\hline Calcium & 1.12933 \\
Cobalt & 0.0000 \\
Nickel & 0.00295 \\
Chromium & 0.00301 \\
Manganese & 0.02001 \\
Lead & 0.0000 \\
Iron & 0.05396 \\
Copper & 0.02736 \\
Zinc & 0.09035 \\
Cadmium & 0.00000 \\
Magnesium & 0.29118 \\
\hline
\end{tabular}

\subsection{Phytochemical Screening}

Table 3 presents the phytochemical compositions of Citrullus lanatus seed oil. This indicated that the seed oil contains terpenoids, cardiac glycosides in all the extracts.

Tannins, steroids, glycosides, alkaloids, balsams and phenols in ethanol extract.

Flavonoids, volatile oil in hexane extract. The presence of secondary metabolites will contribute to its medicinal value as well as physiological activities [8].

Table 3: Phytochemical analysis result of Citrullus lanatus seed oil.

\begin{tabular}{lll}
\hline Compounds & Hexane extract & Ethanol extract \\
\hline Tannins & - & + \\
Steroids & - & + \\
Triterpenoids & - & - \\
Glycosides & - & + \\
Saponins & - & - \\
Alkaloids & - & + \\
Terpenoids & + & + \\
Flavonoids & + & - \\
Carbohydrates & - & - \\
Cardiac glycosides & + & + \\
Resins & - & - \\
Phlobotannins & - & - \\
Volatile oil & + & + \\
Balsams & - & + \\
Phenols & - & + \\
\hline
\end{tabular}

For instance steroidal compounds are of importance in pharmacy, because of their relationship with compounds used as sex hormones [14].Plant terpenoids are used for their aromatic qualities. They play a role in traditional herbs and are under investigation for antibactericidal, antineoplastic and other pharmaceutical functions [12]. Tannins which were present in ethanol extract affect invitro protein digestibility but it is under whether they are detrimental to animal nutrition [15]. Phenolic compounds which were present in the ethanolic extract were reported to exert a wide spectrum of biological effects such as antioxidant and free radical scavenging activities and antimicrobial activities [16], while cardiac glycosides are reported to have antibacterial and antifungal activities.

\subsection{Physicochemical Properties of Citrullus Lanatus Seed Oil}

Table 4 presents the result of the physicochemical properties of oil from Citrullus lanatus seeds. Soxhlet extraction of the oil with hexane gave a light yellow color, the acid value for the sample was $2.2324 \mathrm{mg} / \mathrm{NaOH} / \mathrm{g}$ which falls within acceptable limits of edible oil (less than or equal to $10 \mathrm{mg} / \mathrm{NaOH} / \mathrm{g}$, [17]. While the free fatty acid value of the sample was $1.1162 \mathrm{~g}$.Free fatty value is an important variable in considering the quality of the oil because the lower the free fatty acid, the better the quality of the oil [17].The saponification and peroxide values were slightly high.

Table 4: Physico-chemical properties of citrullus lanatus seed oil.

\begin{tabular}{ll}
\hline Component & Values \\
\hline Iodine value & $177.07 \mathrm{mg} / \mathrm{g}$ \\
Acid value & $2.2324 \mathrm{mg} / \mathrm{NaOH} / \mathrm{g}$ \\
Saponification value & $227.5618 \mathrm{mg} / \mathrm{NaOH} / \mathrm{g}$ \\
Peroxide value & $20.37 \mathrm{~m} \mathrm{Eq} / \mathrm{kg}$ \\
Free fatty acid & $1.1162 \mathrm{~g}$ \\
Viscosity & $44.4 \mathrm{~mm}^{2} / \mathrm{sec}$ \\
Density & $0.918 \mathrm{~g} / \mathrm{ml}$ \\
Moisture & $0.49 \pm 0.07$ \\
R F value (TLC) & $0.86 \mathrm{~cm}, 0.91 \mathrm{~cm}$ \\
\hline
\end{tabular}

\section{Conclusion}

The present results showed that Citrullus lanatus seed was rich in protein. The high quality of oil content was an indication that Citrullus lanatus seed is another ready source of oil like soya beans seeds, but needs to be refined. From the results, Citrullus lanatus seeds are also rich in magnesium and calcium which help to regulate blood pressure and the metabolism of carbohydrate, which has a beneficial effect on blood sugar as well.

\section{References}

[1] Sodeke VA. Extraction of oil from Citrullus lanatus (water melon) seed and analysis. Quarterly Research Services. 2005; 25-30.

[2] Ensminger $\mathrm{AH}$ and Ensminger MK for Health: A Nutrition Encyclopedia Choris califonia pegus press. 1986:1061 - 1072 . 
[3] Cho E, Seddon YM, Roser B, Willet EC and Hankison SE. Prospective study of intake of fruits, vegetables, vitamins and caroteroids and risk of age related Maculapathy 2004; 883 892.

[4] AOAC. Official methods of analysis 15th edition, Association of Official Analytical Chemists. Washington DC.1990; 8:7091.

[5] AOAC. Official methods of analysis 13th edition. William Horwitz edition Washington DC. Association of Official Analytical Chemists. 1980; 7:56- 132.

[6] Harbone JB. Phytochemical methods. Chapman and Hall ltd. London. 1973.49 - 188.

[7] Trease GE and Evans WC. Trease and Evans Pharmacognosy. A physicans guide to herbal medicine.13th edition, Balliere Tindall London. 1989; 56-58.

[8] Sofowora LA. Medical plants and traditional medicine in Africa. Spectrum Books Ltd, Ibadan.1973; 55-71.

[9] Onwuka GI. Food Analysis and instrumentation. Theory and practice. Napthalic prints and structure. Lagos, Nigeria. 2005; $219-230$.
[10] Jones MM, Johnson DO, Netterville JT, Wood JI and Jostens MD. Chemistry and Society. 5th edition. Saunders College Publishers. USA, 1985; 521-577.

[11] Pamela CC, Richard AH and Denise RF. Lippincott's illustrated Relieves Biochemistry 3rd edition Lippincott Williams and Wilkins, Philadelphia. 2005; 335-388.

[12] Michael WK. Medical Biochemistry.3rd edition. Queen Mary Publishers London. 2007; 13-17.

[13] Brady NC. The Nature and Properties of Soil.8th ed., Macmillan Publishers C. O. Inc. New York, 1974; 40-45.

[14] Okwu DE. Evaluation of the chemical composition of indigenous species and flavouring agent. Global Y. Pure and Applied Sciences. 2001; 7:445-469.

[15] Ramachandra G, Virupaksha TK, Shadaksharaswamy M. Relation between rennin level and in vitro protein digestibility in finger mellet (Eleusine coracora Gaertn). J. Agric. Food Chem., 2005; 5:1101 - 1104 .

[16] Cowan MM. Clinical microbiology reviews. 1999; 564-582.

[17] Bally AE industrial oil and fat product.3rd edition 1982:11 28. 